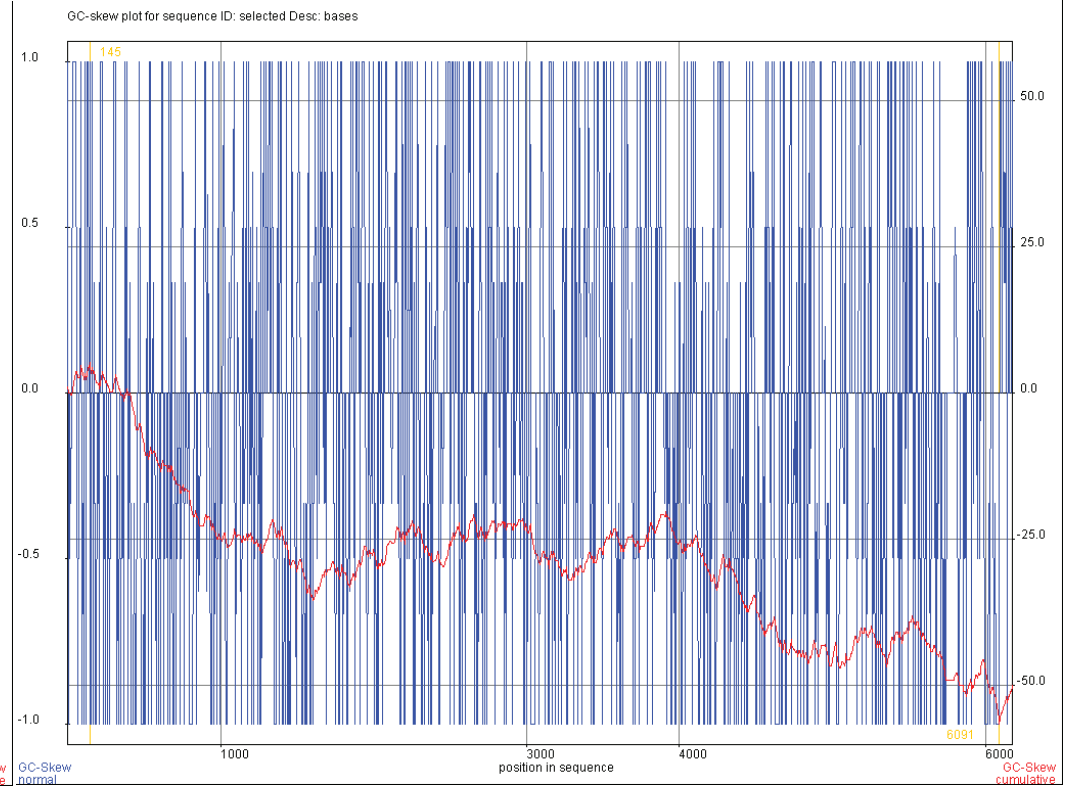

1 .

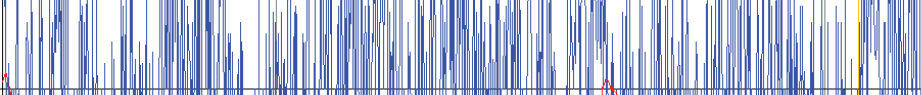
0.0 A. (O. (x)

(I)

\title{
C MA06-7296
}

\section{DPG_3A-IS}
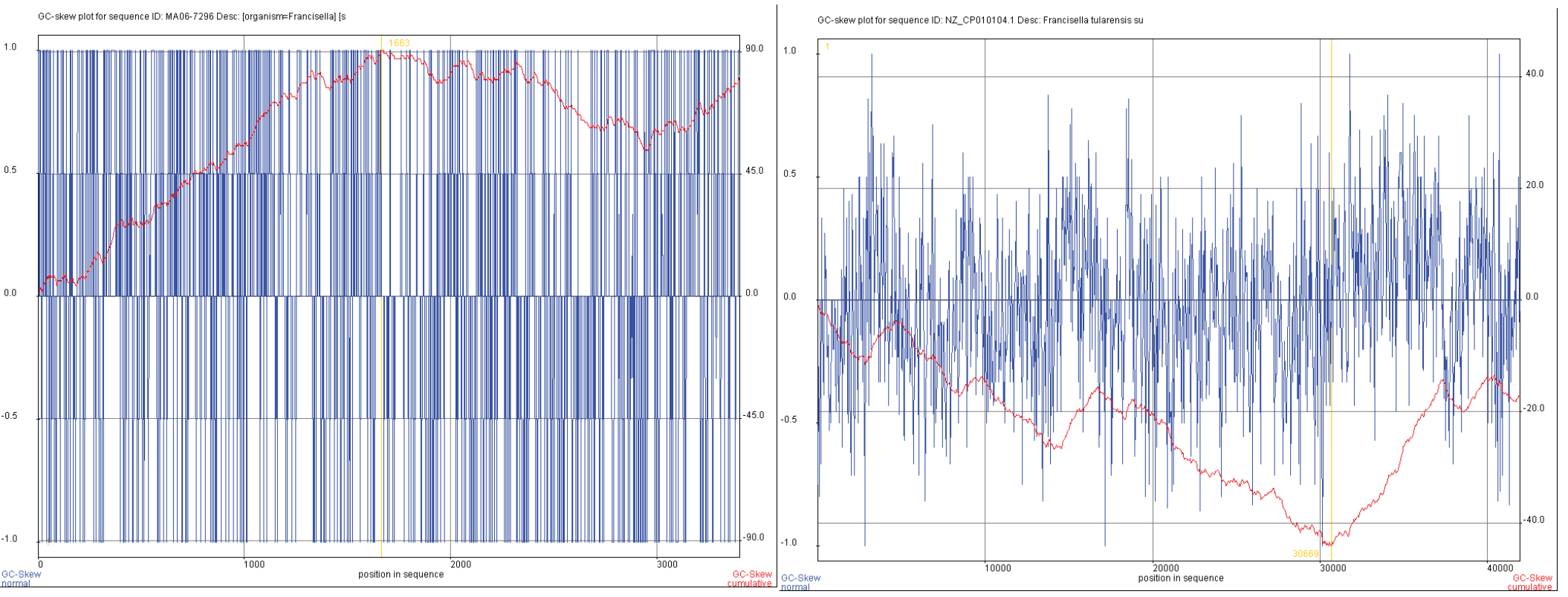

\section{E FSC454}

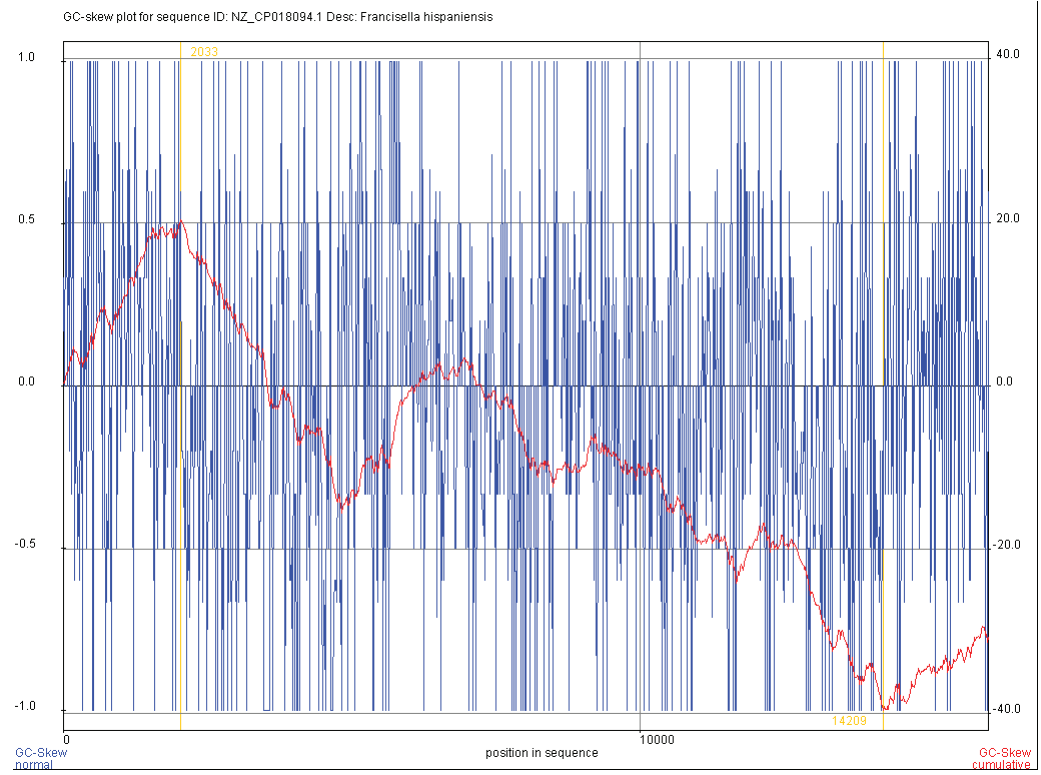

